\title{
Darkness's Descent on the American Anthropological Association
}

\author{
A Cautionary Tale
}

\author{
Alice Dreger \\ Published online: 16 February 2011 \\ (C) The Author(s) 2011. This article is published with open access at Springerlink.com
}

\begin{abstract}
In September 2000, the self-styled "anthropological journalist" Patrick Tierney began to make public his work claiming that the Yanomamö people of South America had been actively_indeed brutally-harmed by the sociobiological anthropologist Napoleon Chagnon and the geneticist-physician James Neel. Following a florid summary of Tierney's claims by the anthropologists Terence Turner and Leslie Sponsel, the American Anthropological Association (AAA) saw fit to take Tierney's claims seriously by conducting a major investigation into the matter. This paper focuses on the AAA's problematic actions in this case but also provides previously unpublished information on Tierney's falsehoods. The work presented is based on a year of research by a historian of medicine and science. The author intends the work to function as a cautionary tale to scholarly associations, which have the challenging duty of protecting scholarship and scholars from baseless and sensationalistic charges in the era of the Internet and twenty-four-hour news cycles.
\end{abstract}

Keywords American Anthropological Association · Anthropology ·

Darkness in El Dorado · Napoleon Chagnon · James Neel · Patrick Tierney · Yanomamö

I ask readers to keep the following notes on methodology in mind as they consider the findings of this paper: This commentary results from a year of historical research that involved the collection of over a thousand source items, including published works, audio and visual recordings, private correspondence, and approximately 40 original interviews. When I interviewed people orally, I gave interviewees my notes and asked them to take some time to change the notes however they wanted, so that I

\footnotetext{
A. Dreger $(\square)$

Medical Humanities and Bioethics Program, Feinberg School of Medicine, Northwestern University, 750 N. Lake Shore Drive, Suite 625, Chicago, IL 60611, USA

e-mail: a-dreger@northwestern.edu
} 
had on the record exactly (and only) what they wanted. I use only their approved versions. For all the sources I have herein marked "personal communication," I have obtained permission for use from the communications' authors.

I come to the work I present here by way of two vocations, one as a historian of science, and the other as a human rights activist. (My rights work has focused mainly on people born with norm-challenging bodies.) Because I care deeply about both science and human rights activism, and because I have been both a critic of some science and also a target of some activist criticism, I have been working on a book aimed at understanding how to protect science and activism-including from each other-in the era of the Internet.

When I circulated word of my book project in 2008, many scientists in evolutionary anthropology and psychology told me I had to look into what had happened to Napoleon Chagnon and to the reputation of the late James V. Neel with regard to the Darkness in El Dorado controversy. As I began researching that history, it quickly became clear that several fine scholars and a number of major scientific organizations had already meticulously exposed the falsehoods about Chagnon and Neel put forth by Patrick Tierney, the author of Darkness in El Dorado (2001) and a related New Yorker article of 2000. Most importantly these scholars had repeatedly shown that, in his work, Tierney had painted what amounted to a fictitious picture of a measles epidemic among the South American Yanomamö people in 1968. (I recommend especially Turner and Nelson 2004, but see also, for example, Alberts 2000; American Society of Human Genetics 2002; Baur et al. 2001; Cantor 2000; Cox 2001; Hagen et al. 2001; Headland 2001; Paul and Beatty 2000; Society for Visual Anthropology 2000; Tooby 2000.)

In his 2000 accounts of the 1968 epidemic (including his New Yorker article and book manuscript), Tierney had portrayed the anthropologist Napoleon Chagnon and the late geneticist-physician James V. Neel, Sr., as virtually amoral eugenicists bent on conducting inhumane and deadly field experiments on a phenomenally vulnerable population. Tierney suggested that Neel-with Chagnon's collaboration-had introduced a potentially fatal contraindicated measles vaccine to the Yanomamö, probably inducing the 1968 epidemic, allowing him to test his eugenic theories. Moreover, Tierney suggested that Neel and Chagnon intentionally withheld medical treatments that might have saved lives. The Neel and Chagnon of Tierney's visions were nothing less than monsters in the guise of modern scientists-monsters responsible for the death of hundreds if not thousands of Yanomamö men, women, and children.

The truth was quite the opposite. From prior field research, before the 1968 epidemic, Neel had determined that the Yanomamö were alarmingly vulnerable to measles, and so he had personally arranged to bring vaccines on the 1968 expedition. Neel had not taken the matter lightly; he had consulted experts regarding the best vaccine to use, obtained instruction about safe administration, and personally arranged the financing to make the vaccination campaign possible (see Lindee in Hagen et al. 2001:61-63; Turner and Nelson 2004). When the party arrived for what was supposed to be a typical expedition combined with a vaccination campaign, measles had already broken out (Headland 2001). Understanding the scope of the danger, Neel, Chagnon, and the others raced to try to contain the epidemic and get ahead of it with the vaccines. The medical supplies 
began to run out before everyone could be appropriately vaccinated, but it was not because of some neglect on Neel's or Chagnon's part (Turner and Nelson 2004).

The independent scholars who came to this history before me had clearly already shown that, far from being remembered as a monster as Tierney would wish, Neel really ought to be remembered as a great humanitarian. For his part, Chagnon ought to be remembered not as the genocidal maniac of Tierney's fantasy, but as the key provider of logistics during the frantic medical response to the tragic epidemic.

I had to wonder when I came upon this story years after all this, given the reality as evidenced by so very many documentary sources, how did Tierney's falsehoods get as far as they did? To answer that, one must really understand how and why certain individuals - but especially leaders within the American Anthropological Association (AAA) - played a supporting role to Tierney's work. This was a supporting role that ultimately threatened the AAA's integrity and indeed the integrity of American anthropology itself. Thus, while this paper provides some previously uncollected and critically informative background material on Tierney's work, it chiefly seeks to highlight the problematic aiding and abetting of Tierney by scholars who had the power to know better and to do better.

\section{Darkness Descends}

In September 2000, Patrick Tierney's work on the South American Yanomamö people, which culminated in the book Darkness in El Dorado: How Scientists and Journalists Devastated the Amazon (Tierney 2001), became internationally known because of the distribution of a memo written by Terence Turner and Leslie Sponsel to the AAA leadership (Turner and Sponsel 2000). Yet in fact, for more than a decade before this, Turner, Sponsel, and a number of Brazilian anthropologists had been trying to go after Chagnon for his work on the Yanomamö (Carneiro de Cunha 1989; Sponsel 1998; Turner 1994). Turner and Sponsel were particularly critical of Chagnon's sociobiological approach. Nevertheless, these earlier objections had not really grown legs, perhaps because Chagnon had forcefully responded to claims he saw as untrue and wrong-headed (Chagnon 1989), or perhaps because the objections were not nearly as sensationalistic as Tierney's would turn out to be.

Long before Tierney's book, Chagnon-a forceful, fearless, prominent, and articulate promoter of sociobiological anthropology - had also acquired detractors in camps beyond anthropology. In the early 1990s, someone started distributing anonymous anti-Chagnon packets at the AAA meetings and directly through the mail to Chagnon's colleagues (Fox 1994; Wolf 1994). Anthropologist Frank Salamone (1997:97) has revealed that these defamatory packets were actually being distributed by the Roman Catholic Salesians whose missions Chagnon had been publicly criticizing, saying that the Salesians were thoughtlessly harming the Yanomamö.

So it wasn't as if Chagnon had not already been the subject of various slings and arrows. But in interviews, Turner and Sponsel both suggested they were frustrated over the failure of the various pre-Darkness charges against Chagnon to garner much 
attention (Sponsel 2009; Terence Turner 2009). Tierney's book appeared to represent a rich new opportunity for drawing attention to Chagnon's alleged misdeeds. Upon receiving prepublication copies of the book, Turner and Sponsel decided to coauthor their memo advising the AAA leadership of an impending scandal.

The Turner-Sponsel memo-a truly extraordinary piece of work-began by stating that, "In its scale, ramifications, and sheer criminality and corruption, [the scandal] is unparalleled in the history of Anthropology." In florid prose, Turner and Sponsel then uncritically related Tierney's most sensational claims, including that the geneticist James Neel had "in all probability deliberately caused" an outbreak of measles by using a contra-indicated vaccine among the Yanomamö to test an "extreme," "fascistic" eugenic theory. Chagnon was accused, in the Turner-Sponsel memo, of supporting Neel's efforts by doing research that "formed integral parts of this massive, and massively fatal, human experiment." Additional charges included "cooking and re-cooking" data, intentionally starting wars, aiding "sinister politicians" and illegal gold miners, and purposefully withholding medical care while subjects died (Turner and Sponsel 2000).

In retrospect, this memo should have been met by all with serious skepticism. But as I've learned from my research into this and other controversies (e.g., Dreger 2008), the most unbelievable claims seem like they must be believed (cp. Howell 2001). Because how could you make this stuff up?

Turner and Sponsel claimed to me to be surprised over the distribution of their memo to the international press (Sponsel 2009; Terence Turner 2009), but they had not chosen to mark their memo as confidential. Even if they had, would that have made their uncritical — seemingly enthusiastic - relaying of outrageous claims to the leaders of American anthropology appropriate? I think not. Regardless, the leak of their handiwork served to do what they wanted done: it forced the AAA to finally act on Chagnon (Terence Turner 2009). Responding to screaming headlines - like the one in The Guardian reading "Scientist 'Killed Amazon Indians to Test Race Theory" (Brown 2000) — the AAA held a jam-packed special session on the book at the next meeting, in November of 2000, in San Francisco. Tierney sat on the panel, as did the anthropologist Bill Irons in defense of Chagnon (his best friend); the historian Susan Lindee (a leading biographer of Neel); and others. Virtually everyone on the panel objected to Tierney's misrepresentations-Lindee had concrete historical proof that Tierney was wrong about Neel's actions - but Tierney found plenty of sympathizers in the audience (Lindee 2008).

After the contentious meeting, the AAA's President Louise Lamphere took the matter still further. The AAA formed the Peacock Commission, whose confidential report called for the formation of what became known as the El Dorado Task Force. Chaired by the past AAA President Jane Hill, the AAA's Task Force was charged with inquiring into issues raised by Tierney's book. The Task Force included Janet Chernela, Fernando Coronil, Trudy Turner, and Joe Watkins. Under pressure from Chagnon's colleagues, a collaborator of Chagnon was added late to the Task Force (AAA 2002a). That was Raymond Hames. Hames resigned before it ended, claiming the problem of the appearance of conflict of interest (Hames 2002). The Task Force's Report, formally faulting Chagnon on two counts, was accepted by the AAA board in May 2002 (AAA 2002b). (I address those two counts below.) 
Meanwhile, by contrast to the AAA, many other professional institutions and academic researchers quickly found Tierney's book to contain so many falsehoods as to itself represent a scandal. These included the National Academy of Sciences (Alberts 2000), the American Society of Human Genetics (2002), the International Genetic Epidemiology Society (Baur et al. 2001), the Society for Visual Anthropology (2000), and the Provost's Office of the University of Michigan (Cantor 2000). These groups recognized that whistle-blower protection applies only to those who whistle the truth. But the AAA did not join suit in defending its field's researchers against Tierney's fundamentally false accusations, and instead used Tierney's book as the justification and the template for a major inquiry into the behaviors of Neel and Chagnon.

The AAA Board may have thought they put the matter to bed in 2002 when they accepted the Task Force's Final Report (AAA 2002b). But in 2003, the voting AAA membership passed a referendum condemning misrepresentations of the 1968 epidemic, implicitly criticizing Tierney, Turner, and Sponsel, and explicitly criticizing the Task Force for "fail[ing] to properly recognize that the [false] charges that initiated their investigation are themselves dangerous" (AAA 2003). The referendum had been drafted by anthropologists Tom Gregor and Dan Gross and passed by a ratio of 11 to 1 . (Approximately $14.5 \%$ of those eligible to vote did so [Kimberley Baker, AAA Section \& Governance Coordinator, to Alice Dreger, personal email communication, January 4, 2011].)

Then in 2005, following a scathing analysis they published in American Anthropologist (Gregor and Gross 2004), Gregor and Gross put forth a second referendum calling for complete rescission of the acceptance of the Task Force Final Report (AAA 2005). The rescission referendum passed by a ratio of about 2.5 to 1 . (Approximately $11 \%$ of those eligible to vote did so [Baker to Dreger, personal email communication, January 4, 2011].) The AAA leadership thus seems to have been out of step not only with all other institutions involved, but with its own active membership.

\section{More Examples of Tierney's Illusions}

I have already noted how many other scholars have documented key falsehoods in Tierney's work, and there is no gain in (nor space for) my reiterating their work point by point. But I do want to provide a few more telling examples of Tierney's falsehoods not previously documented. These falsehoods are important to expose in and of themselves, but in exposing them, I also want to impress upon the reader how it appears that any and all independent scholars coming upon this work find more and more evidentiary holes. It is rather like shooting fish in a barrel. The ease of this fish-shooting in turn raises the question of why The New Yorker, which published an advance article by Tierney, and W.W. Norton, which published the book, did not do their homework in terms of factchecking. It also raises the question of why the AAA kept using Tierney's book as a roadmap rather than stopping to ask who this mapmaker was and where he got his information. 
So, to begin a sampling of what I personally uncovered: On page 60 of Darkness, in writing of the key 1968 measles epidemic among the Yanomamö, Tierney writes, "The vaccinators were Napoleon Chagnon and a respected Venezuelan doctor named Marcel Roche" (2001:60). Reading this in my work, I quickly recalled that Chagnon had told me in interviews he did not do vaccinations (Chagnon 2009). This is a nontrivial point since Tierney had claimed, though erroneously, that Yanomamö were seriously harmed - even killed — by a vaccine that was outdated and contraindicated. So I was surprised to see that Tierney's citation for the claim that Chagnon was vaccinating was page 421 of the Neel et al. article on the epidemic, because I knew that was an article Chagnon himself had co-authored (Neel et al. 1970). How could Chagnon co-author a claim that he vaccinated in 1968 and then turn around and tell me he didn't?

In preparation for calling Chagnon to ask him to explain the discrepancy, I pulled the article cited. There is indeed a page 421 in the article, but that's as far as the truth of the citation goes. In fact, nowhere in the article is any single vaccinator named. As I and others have found, this is typical of Tierney's meticulous-appearing, copious citations. And his citations are, of course, how he gained such legitimacy. When Tierney was interviewed in late 2000 on Chicago Public Radio, interviewer Victoria Lautman gushed,

There are 60 pages just of footnotes supporting Tierney's incendiary main point[s], namely that the Brazilian Yanomamö Indians were hideously exploited, that a lethal 1968 measles epidemic was spread by a dangerous vaccine, that the U.S. Atomic Energy Commission used the Yanomamö as a control group without their knowledge, and, most important, that all of these shocking abuses were perpetrated by two of the most famous and respected members of the anthropological community (sic; Lautman 2000).

Yet - like the example I just provided — many of Tierney's hundreds of citations lead nowhere. Others essentially say the opposite of what is claimed.

Lautman's uncritical swallowing of hook, line, and sinker indicates that Tierney's story represented what journalists call "too good to check." In the current media market, reporters are rewarded for primacy and speed, not for accuracy. People like Tierney can thus get far with a lot of untruths if their story is especially juicy. But it is worth noting that, had Sponsel and Turner and the AAA leadership bothered to pause and check - had they elected to act like scholars and not like mere reportersthe journalists promoting Tierney's work might have soon realized how wrong it was, and Tierney's book might not have reached the point of being named a finalist for the National Book Award.

Let us consider another historically very important example of misrepresentation. On the first page of his book's Acknowledgments, Tierney writes, "I am especially indebted to Leda Martins. . . . Leda's dossier on Napoleon Chagnon was an important resource for my research" (Tierney 2001:xvii) The dossier to which Tierney is here referring was used for years before Darkness to try to stop Chagnon from obtaining further research permits to do his fieldwork. The dossier-copies of which I obtained from Chagnon and Martins - reads rather like a "coming attractions" synopsis of Darkness, so precisely does it presage the wild claims of the book. 
So in crediting Martins with the dossier, Tierney seems in his Acknowledgments to be claiming that Martins was a source for him of much of the (false) dirt about Chagnon. The truth, the former journalist and now-anthropologist Martins told me, is that Tierney himself wrote the muckraking dossier that Tierney credits to her (Martins to Dreger, personal email correspondence, June 5, 2009).

Curiously, when I first asked Martins about the dossier, she told me she had written it: "I wrote the dossier and gave it to Funai" (Martins 2009). But she later changed her claim to me as follows:

Patrick Tierney wrote the Chagnon dossier and I translated [it] to Portuguese. . . . I presented the dossier to Brazilian authorities (Funai employees) and human rights advocates who were looking for information on Chagnon who was seeking permission to go inside the Yanomami Territory in Brazil. I was the one who circulated the dossier in Brazil because people knew and trusted me. I trusted Patrick and did not check his references. (I can only hope whatever is left of my friendship with Patrick will survive the truth, but . . . he should not have said that.) (Martins to Dreger, personal email communication, June 5, 2009)

So Tierney himself had apparently written the dossier that presumably contributed to Chagnon being denied research permits. Not only does Tierney not admit this, he obscures the point by thanking Martins for the dossier.

This revelation from Martins is quite stunning-for it means Tierney had started working to take down Chagnon years earlier, in a much more direct fashion, one that he apparently never revealed and indeed tried to foist off onto Martins - and yet it is even more stunning when taken in conjunction with an email from November 6, 1995, sent from Napoleon Chagnon to Raymond Hames:

I finally made, with the help of a Brazilian friend, a translation of the "Dossier" on me that is circulating in Brazil and was used in September to try to have FUNAI rescind my permit. It is so hysterical and preposterous that it is funny, but there will be lots of people who will believe the[se] claims. . . Footnote \#21 leads me to suspect that the primary author of this is one Patrick Tierney, who actually showed up in my office just after I returned from Brazil. I pointedly asked him if he were aware of this "dossier" and he denied any knowledge of it. I think he is a liar.

Notably, right about the time Chagnon was writing this to Hames in 1995, Patrick Tierney was introducing Lêda Martins to Terence Turner, at the Pittsburgh airport (Martins 2009; confirmed in Terence Turner 2009). The three-Tierney, Martins, and Turner-would continue to meet several times there over the next few months. Within a few years, Martins went on to earn her Ph.D. in anthropology under Turner, and to publish criticisms of Chagnon, including via a spin-off volume from the AAA Task Force (Borofsky 2005). And Tierney went on to publish Darkness, a book that would seem to guarantee the ruin of the reputation of Turner's long-time nemesis, Napoleon Chagnon (Miller 2000).

Many others besides Martins have also denounced Tierney's attributions to them, including, for example, the vaccinologists Francis Black of Yale, Samuel Katz of Duke (Cohen 2000), and Mark Papania of the CDC (Tooby 2000). Even those who 
were once allied with Tierney have said he misrepresented them. Martins is obviously one example, but another is the anthropologist Brian Ferguson, whom I asked about his experience with Tierney. Ferguson has been highly critical of Chagnon's distribution of trade goods among the Yanomamö, and has argued this has significantly contributed to tensions, violence, and cultural disruption (Ferguson 1995). Ferguson told me that in many places Tierney did represent him correctly. But:

I was sent the prepublication copy of the New Yorker article. They called me to fact-check and everything was fine except one passage where Tierney has me saying something to the effect of "missions could be disruptive but according to Ferguson they are less so than Chagnon was," downplaying the impact of the missions. I said, no I didn't say that, and I don't believe that to be true. I think [the missions] were very disruptive in the period I'm talking about. . . . I said that's not what I said. And I got a call from Patrick Tierney and he got quite angry about it and said that I was backing down and that I was making a political move here and that he had me on tape saying what he said I said. And I said you'd better get that tape ready, because that's not what I said (Ferguson 2009).

Ferguson also told me:

the missions have had a very destabilizing effect on the Yanomami and the missions seem to be unconscious of how much they've encouraged conflict among Yanomami groups. That's a big thing in my book. But it's not a big thing in Darkness in El Dorado. The missionaries are pretty much uniformly critical of Chagnon. So if you're against Chagnon, Tierney is going to put you in there in a positive light, and that's what Tierney does (Ferguson 2009).

That is indeed what Tierney does: tell a fairly simple tale of good and evil- the missions are good, Chagnon and Neel are evil-but not a non-fiction tale.

In spite of all this evidence against Tierney, a few anthropologists have tried to find new evidence to salvage what they can of Tierney's claims against Neel and Chagnon. This is particularly true in the case of Terence Turner. Turner, who helped Tierney while he was writing the book (Tierney 2001:xviii; Miller 2000), has since tried to salvage Tierney's claims by digging through Neel's papers, producing copious annotations (Turner and Stevens 2001). Turner is still apparently convinced that Neel's funding from the Atomic Energy Commission must have meant some kind of nefarious activity (Terence Turner 2009). Barbara Rose Johnston has hinted similarly (Johnston n.d.) But this digging has not panned out, and in fact, as historians Diane Paul and John Beatty have noted, "by the late 50 s and early $60 \mathrm{~s}$, [the AEC] funded approximately one-half of all federally funded genetic research in the U.S." (Paul and Beatty 2000). Meanwhile anthropologist John Frechione has done extensive work on a paper with Tierney trying to show that Neel's movements during the 1968 epidemic put science before emergency medical care (Frechione 2009), but again, nothing seems to have come of this salvage operation.

Turner and Frechione have also both tried to help Tierney's case by conducting interviews with Brandon Centerwall, the physician son of late physician Willard 
Centerwall (Frechione 2001; personal email correspondence Turner to Dreger, February 13, 2009, reflecting interview by Turner of Brandon Centerwall in April 2002). Willard Centerwall had been on the fateful 1968 expedition, and soon after he returned, Willard claimed to his then-teenage son that Neel had wanted to purposely let the epidemic run unchecked among the Yanomamö at Patanowa-teri. Willard told his son that, in Patanowa-teri in 1968, Willard had been morally outraged by Neel's supposed denial of emergency medical care, that Willard stood up to Neel, and that Neel backed down and called for additional medical supplies. Turner and Frechione both got Brandon Centerwall on the record remembering this story from his father. When I came to this story, I realized that to a nonscholar, Brandon's story might seem to bolster Tierney's otherwise collapsing claims against Neel. The Centerwall story was certainly dramatic. For this scholar, the problem was that it also contradicted pretty much all non-hearsay evidence about these events.

Still, historians don't like to let even very lopsided factual contradictions lie if we can resolve them. So I wrote to Brandon Centerwall and asked him about the memory. Brandon took a few days and wrote back to me the most heart-wrenching response I've ever had from a source (personal email communication dated February 18, 2009; received February 20, 2009). His father's story, Brandon explained in a four-page letter, "was entirely false with regard to those aspects of the story which are of concern to you."

Brandon went on to explain that his father was "a tireless worker, an excellent clinician, and a devoted instructor. . . . He was cheerful and upbeat in character." And he "had a habit of padding his resume" and telling his son stories meant to make him more impressive, and in this case, a hero. Said Brandon, "the painful reality was that [my father] was a coward. . .." Brandon had come to realize that the story of standing up to Neel was one among many tall tales told by father to son "for reasons of ego." Willard had also told his son that he knew some Cantonese because he was in training for intelligence work on the Chinese front during World War II. Brandon later discovered that his father actually knew Chinese because he had had a Chinese girlfriend.

Brandon wrote to me, "Perhaps the simplest, most direct way to an understanding of my father is to be found in James Thurber's short story, 'The Secret Life of Walter Mitty,' a favorite story of my father's." Brandon is now sure his father told him the false story about Neel - in which Willard played the hero - to impress himself and his son: "I am certain that I am the only one to whom he ever told this fiction. . . I suspect he felt confident that nothing would ever come of his telling me this outrageously false account, and he was very nearly right." Brandon concluded, "So the story was false in all pertinent aspects. It makes me heartsick to have to write such things about my father."

I admit it makes me heartsick to have to relay such things about Willard Centerwall. One must wonder why, if they wanted to engage in historical scholarship, Frechione and Turner did not follow the most basic rules of historical scholarship by simply asking Brandon Centerwall to explain the apparent contradiction between Willard's story and the rest of the historical evidence-a question that might have saved Brandon from ever having to air this deeper history of his father. 


\section{So Who is Patrick Tierney?}

In my interview with her, the historian of science Susan Lindee asked a key question: Why did Tierney publish a book so easy to refute? To quote Lindee:

How could [Tierney] publish something so incendiary, if he knew-or should have known - that it could be so easily contradicted? It was so easy to contradict! It took me an afternoon [looking at Neel's papers in response to the Turner-Sponsel memo] to say this central claim did not happen. And others joined in to contradict virtually every claim he made about the vaccine, the biological details, the fieldwork, the sequence of events (Lindee 2008; see also Lindee's letter to colleagues of September 21, 2000, reproduced in Hagen et al. 2001:61-62).

Unfortunately, I have not really been able to figure out why or how Tierney published work so easy to refute. I honestly can't figure out much about Tierney. Among the major players, he was the only person not to respond to my interview requests. It's unusual for an author to be so reluctant to discuss his National Book Award finalist. A mid-2009 search of records conducted by Dalman Investigations at my request indicated that Tierney, then aged fifty-five, had no detectible record of employment history other than publishing two books, The Highest Altar: The Story of Human Sacrifice in 1990 with Penguin, and Darkness in 2001 with Norton. He fashions himself as an anthropological reporter, but apparently he has had no degree, training, or employment in anthropology or journalism.

In my research, I learned that, after his first book, Highest Altar, but before Darkness, Tierney penned a 400-page book called Last Tribes of El Dorado: The Gold Wars in the Amazon Rain Forest for Viking Press. For reasons Viking would not tell me, Last Tribes reached advanced review stage in 1994 or 1995 but was never published. I obtained two identical copies of Last Tribes, one via interlibrary loan and one through an online bookseller. Last Tribes turns out to be a sort of memoir of Tierney's wanderings through the rainforest as he attempts to gather dirt on illegal gold mining operations that are seriously harming the environment and the native peoples, including the Yanomamö. There's not much mention of Chagnon himself in Last Tribes, and no mention of Neel. Chagnon is mostly identified as a subscriber to sociobiology, which Tierney takes to mean any explanation that sees sex, violence, or selfishness as a motivator in human life (Tierney 1994:34-35, 79, 99, 115-116, 170, 219-221).

But we do learn plenty about Tierney in Last Tribes. Tierney reveals that he has lied about his identity repeatedly, including to some indigenous people, by representing himself as a Chilean gold miner (Tierney 1994:29, 75, 87, 88, 131). This was confirmed for me by the Consolata missionary and anthropologist Father Giovanni Saffirio, who occasionally associated with Tierney during this period: "[Tierney] traveled through the area with a fake ID card saying he owned a mining company in Chile where he was born. He cheated gold buyers saying he was eager to open a 'garimpo' (a mining business) in Roraima” (Saffirio 2009).

In Last Tribes, Tierney also admits having repeatedly gone into Yanomamö territory without FUNAI's (the appropriate authority's) legal permission to do so 
(Tierney 1994:19, 124, 127), perhaps because he saw FUNAI as hopelessly corrupt (Tierney 1994:182-183, 205, 210). He carried mercury into the rainforest, as part of his gold miner disguise (Tierney 1994:71). As part of the act, he did a little pit mining himself, knowing full well that it wrecks the environment (Tierney 1994:139, 155). He illegally purchased a shotgun and carried it into indigenous territory (Tierney 1994:71). Time and time again, he met up with murderers-including selfconfessed murderers - and apparently never turned them in to the police (Tierney 1994:69, 115, 138, 149, 163, 396). He flew into remote Yanomamö areas without quarantine (Tierney 1994:172, 181). He stirred up enough trouble that, it seems, he accidentally got a guy killed, because the other man was mistaken for the troublemaking Tierney (Tierney 1994:327). Mind you, this is all reported by Tierney's own hand, and this is all information the AAA could have found as easily as I had, had they decided to first ask who Tierney was, rather than immediately using him as a reason to go after Chagnon and Neel.

Perhaps the most interesting information revealed in Last Tribes is that, in his investigative wanderings, Tierney was fed, housed, protected, and encouraged by the local Roman Catholic priests (Tierney 1994:30, 120, 272, 297, 298). He left his money and real identity papers with the priests (Tierney 1994:50). When he was arrested, it was Bishop Aldo Mongiano who sprang him out of jail (Tierney 1994:216; also indicated in Saffirio 2009). Tierney specifically checked in with and acted as an emissary for this bishop (Tierney 1994:229, 231). At one point in Last Tribes, Tierney remembers having been told, "The bishop is very happy with you" (Tierney 1994:234). I was not too surprised when Saffirio described Tierney to me as "a good Catholic" and added "bishop [Mangiano] was pleased to help him" (Saffirio 2009).

As the AAA would have learned, had they bothered to borrow through interlibrary loan a copy of Last Tribes as I did, so much that Tierney revealed in the unpublished Last Tribes was made invisible to readers of the book that was ultimately published, namely Darkness in El Dorado. For example, Tierney's close relations with the Consolata priests are largely obscured in Darkness. It isn't clear from either book to what extent Tierney worked with or for the Salesian missionaries, the religious group engaged in a long-running battle with Chagnon, the way Tierney apparently did with the Consolata. But Chagnon himself has noted that the Salesians apparently "opened their records to Tierney and gave him free access to them" (in Hagen et al. 2001:110). After trying, mostly fruitlessly, to sort out the mysterious identity of Patrick Tierney, the man the AAA took as their guide, I was simply left struck with the lovely irony that the founder of the Salesians, Dom Bosco, is today the patron saint of illusionists.

Fascinatingly, in our interview, Frechione told me that, since Darkness, Tierney has apparently teamed up with the equally discredited Andrew Wakefield. Readers may recall that in 1998, Wakefield published in the Lancet a highly publicized paper throwing doubt on the safety of the vaccine commonly used to prevent measles, mumps, and rubella (MMR). But Wakefield had failed to disclose what the Lancet editor later termed "fatal" conflicts of interest, and ten of his twelve co-authors retracted the paper. A subsequent ethics investigation by the UK General Medical Council found Wakefield guilty of professional misconduct on numerous counts, 
including undisclosed conflicts of interest and research abuse of subjects, including children. In 2010, Wakefield was struck off the medical register in the U.K., meaning that he can no longer practice as a physician there. As this article was in press, the editors of the British Medical Journal (http://www.bmj.com/content/342/bmj.c7452. full) concluded that Wakefield's Lancet article "was in fact an elaborate fraud."

How interesting that Tierney might now be teamed up with someone who is alleged to have unethically harmed vaccine campaigns through problematic reporting. I was relieved to learn that Darkness in El Dorado does not appear to have resulted in harm to vaccine campaigns in South America, at least according to vaccinologists there with whom I was put in touch with the help of Sam Katz, co-inventor of the measles vaccine (personal email correspondence with Jon Andrus, April 23, 2009, and with Ciro de Quadros, April 21, 2009). But it is hard to know what damage Tierney might do, worldwide, with a new book on vaccines, if taken as seriously next time around as last—as seriously as people like Turner and Frechione still seem to take him.

\section{The Complicity of the AAA}

In his work, Tierney does come across as a man trying to walk in the footsteps of Jesus, carrying sick children out of the woods, rescuing them from criminals (Tierney 1994), and then rescuing them from a mythically evil Chagnon who bears a striking resemblance in Tierney's representations to the gone-native Kurtz in Joseph Conrad's Heart of Darkness. In Tierney's vision (2000), Chagnon even arrives in the deathbringing helicopters of Francis Ford Coppola's version of Kurtz in "Apocalypse Now," leaving villages of dead women and children in his wake. In Lindee's words, "it was like [Tierney] saw himself as the sacrificial lamb, that he was willing to do this for them, that he was the Christ-like figure who would transform things for indigenous groups around the world. Instead of that, he did real damage" (Lindee 2008).

The damage might have been better contained if not for the AAA, whose leaders chose not to make a forceful statement about Tierney's egregious falsehoods. The AAA opted to do nothing like what my own home organization, the American Society for Bioethics + Humanities, did in 2009 to defend bioethicists Ezekiel Emanuel and Robert Pearlman against false representations of their work by journalists (Lindemann et al. 2009). While the Peacock and the Task Force Reports contain some critiques of Tierney, both explicitly took Tierney's book as the roadmap to follow for further inquiries. Both even essentially thanked Tierney on behalf of anthropologists. The Peacock Commission concluded this: "Patrick Tierney's provocative book, Darkness in El Dorado, has contributed a valuable service to our discipline" (Peacock et al. 2001). The Task Force later concluded this: "Darkness in El Dorado has served anthropology well” (AAA 2002a:9). No other scholarly organization treated Tierney's house of cards as constituting a valuable service to their discipline.

What's really disturbing is that so many people who participated in the AAA's investigations of Neel and Chagnon seem to have understood what Tierney's book really amounted to. For example, Janet Chernela, who served on both the Peacock Commission and the Task Force, told me this: “Nobody took Tierney's book's claims seriously. I was surprised that James Peacock, who is a very careful and fair 
person, favored going forward with the Task Force" (Chernela 2009). This begs the question of why Chernela went forward with an investigation that followed the path of Tierney. Compare the words of Jane Hill, the former president of the AAA who chaired the Task Force. On April 15, 2002, after Hames resigned from the Task Force, Sarah Hrdy wrote to Jane Hill objecting to the situation and got this response from Hill:

Burn this message. The book is just a piece of sleaze, that's all there is to it (some cosmetic language will be used in the report, but we all agree on that). But I think the AAA had to do something because I really think that the future of work by anthropologists with indigenous peoples in Latin America-with a high potential to do good-was put seriously at risk by its accusations, and silence on the part of the AAA would have been interpreted as either assent or cowardice. Whether we're doing the right thing will have to be judged by posterity. (Obtained via email from Hrdy, November 6, 2009; used with Hill's permission from November 6, 2009; emphasis in original.)

So, even though Tierney's book was "just a piece of sleaze," Chagnon, the late Neel's legacy, the Chagnon and Neel families, and these two men's colleagues were put through a major investigation to preserve the field for other American anthropologists? Why did Hill not say publicly what she said to Hrdy? Why not admit that Chagnon must be publicly strung up to save anthropology from "just a piece of sleaze"?

Let me be clear: I understand the desire - and the duty — on the part of people like Lamphere, Peacock, and Hill to try to preserve the ability of American anthropologists to study in South America. But this way?

Did the Peacock Commission really need to act like a grand jury, hastily issuing a sealed indictment, never pausing to really examine whether the evidence warranted an indictment, in spite of multiple authoritative and well-publicized denunciations of Tierney's fakeries? I think not. Indeed, the Peacock Report should come as a shock to any scholar worth her salt. (A copy of it has recently been made available at the Hume online archive [Peacock et al. 2001].) Not only is it a mess in places in terms of reasoning and lacking basic formatting consideration, the report itself states that it was prepared so hastily that not all members of the Peacock Commission were able to approve the final version. One has to wonder, if the life's work of your colleague is on the line, can you not take some extra time to produce a report you feel comfortable showing to the membership of your supposedly democratic scholarly organization? Apparently not if you think your job is utilitarian public relations damage control.

In the event, the Peacock Commission specifically called for an "investigation" into alleged ethical transgressions. Inconveniently, the AAA's bylaws did not allow for adjudication of ethics complaints. Thus, the El Dorado Task Force was charged with doing an "inquiry" instead (Gregor and Gross 2004:688). Here, "inquiry" versus "investigation" was a distinction without much difference. The Task Force's report basically begins in earnest with a statement summarizing which ethical violations Chagnon was found to be guilty of (AAA 2002a; see vol. 1 sec. 2.2). The media advisory from the AAA alerts the press to the ethics findings (AAA 2002b). Not an ethics investigation? And consider some quantitative data: Excluding pages 
that are front matter, methods statements, and c.v. reproductions, fully two-thirds of the pages of the Task Force's Final Report explicitly involve investigations into whether Neel or Chagnon acted improperly. Finally, in her interview with me, Jane Hill stated plainly, "The final report did include an evaluation of Chagnon. We dismissed the charges against Neel" (Hill 2009). "Dismissed the charges," and yet it was not a prosecution?

I want to be clear: The issues raised in the Task Force Report-including informed consent, the effects of gift-giving, the representation of vulnerable subjects, and so forth - are undoubtedly worth examining, and some of the examinations represented quality scholarship. But as an analogy, I would also say the issue of how monied interests and ethnic tensions contribute to terrorism are worth examining with quality scholarship, too, but I would not want to see those inquiries happen in response to some crackpot's false claim that a Jewish conspiracy was at the center of the 9-11 attacks, no matter how many fake citations the crackpot sported. If the AAA leadership felt the AAA should have responded formally earlier to the Brazilian Anthropological Association's complaints about Chagnon-and it isn't clear they should have - that does not really excuse using Tierney as a roadmap. It certainly doesn't excuse thanking him for "valuable service."

I believe, and many others I spoke with agree, that Jane Hill worked hard and with good intentions chairing this Task Force. I admire her for going to listen for herself to the tapes of the expedition, wherein she, too, found that Tierney was misrepresenting sources (in AAA 2002a; see vol. 2 sec. 6.1.2). Joe Watkins took seriously the difference between ethical reflection and a personalized ethics investigation (see, e.g., in AAA 2002a, vol. 2 sec. 6.2.4). Trudy Turner, helped by Jeffrey Nelson, did an astoundingly good bit of historical research to refute Tierney's and Terence Turner's claims about Neel (in AAA 2002a; see also Turner and Nelson 2004). Indeed, Trudy Turner's work on Neel represented the pinnacle of the scholarship required in an honest ethics investigation. But I think the job of the Task Force, as a whole, was bungled, badly.

As previously noted, the report does not defend anthropologists against the likes of Tierney by clearly, forcefully summarizing the extent of Tierney's fabrication and condemning it. Moreover, the AAA had no provisions for the ethics investigation that a substantial portion of the Final Report clearly represents (Gregor and Gross 2004). One must wonder what scholar will want to belong to a professional organization which, rather than protecting her right to be fairly represented in the press, launches an investigation into her life's work, producing reports-one even kept undisclosed, in the case of the Peacock Report-that take seriously an uncredentialed journalist whose major claims were shown, at the outset, to be false? I can't imagine how any scholar now feels safe at the hands of the AAA, except insofar as the voting membership seems to have some sense of fair play.

The problems with the Task Force extend further: Though this process had many elements of an ethics investigation, never was Chagnon formally invited by the AAA to defend himself. This must have been because the AAA was doing an ethics investigation without being clear about that. Thus the Task Force had no clear procedures and seemed to make up the rules of the inquiry as they went along. Lamphere did invite Chagnon to attend the San Francisco meeting (Chagnon 2009), but once the Task Force was launched, no formal communications from the AAA 
leadership to Chagnon followed. Hill told me, "A decision was made not to talk to him. I don't remember the circumstances” (Hill 2009).

And this failure to formally invite Chagnon to defend himself happened in spite of the fact that the Task Force chose to broadcast novel reputation-wrecking claims about Chagnon-for example, the claim from Yanomamö spokesperson Davi Kopenawa that Chagnon had paid his subjects to kill each other, and had offered to pay per killing (in AAA 2002a, vol. 2, p. 35). Janet Chernela's reasoning for reproducing such an outrageous claim by Kopenawa-whose broadcasting could well have hurt Kopenawa even more than it hurt Chagnon-was that it was necessary to give voice to the indigenous peoples (Chernela 2009). But the AAA chose to "give voice" very selectively.

What's even more troubling is that the Task Force seems to have read the Yanomamö testimonies selectively, too, using them sometimes to support prosecution of Chagnon, but not to exonerate him. For example, the Task Force seems to ignore the fact that, in replying to a question about Chagnon's supposed misrepresentation of the Yanomamö as a violent people, Davi Kopenawa denounces Chagnon's characterization - and then proceeds to give an account of Yanomamö aggression astoundingly close to Chagnon's (in AAA 2002a, vol. 2, p. 32). Like Chagnon, Kopenawa even uses, as his hypothetical example for talking about fighting, the motivation of woman-stealing! If Chagnon made this stuff up-about elaborate Yanomamö duels with lethal weapons centered around sex-Davi Kopenawa must be guilty of plagiarizing Chagnon.

The problems go on: In spite of his letter of resignation (Hames 2002), which clearly stated he wanted his name off the report, Raymond Hames's name was left in the report's Table of Contents; his c.v. was reproduced therein, as if he remained on the Task Force; and his name was not removed from individual essays, even after material with his name on it was changed. This seriously violates norms of scholarly publishing, regardless of the fact that a discussion of this appears in the preamble. Of course, keeping Hames's name and c.v. added legitimacy to the report, exactly the opposite of what Hames wanted when he resigned.

It is worth noting that Hames now admits that, though he only said in his letter of resignation that he resigned to avoid the appearance of conflicts of interest, he really wanted to get off a train he saw as heading for a wreck. He told me the Task Force was "a kind of show trial" and he wanted no further part (Hames 2009). When I mentioned Hames's resignation to Trudy Turner, it was obvious she had shared some of Hames's concerns. Trudy Turner said to me, “[Hames's resignation] left me in a very difficult position. If I had bailed, who would have been left? I felt like I couldn't. Then they could have written anything they wanted about Neel" (Trudy Turner 2009). What a chilling situation for a scholar to find herself in.

On top of all this, the Task Force's Final Report is riddled with basic formatting problems that make reading and understanding it a serious challenge. For example, the pagination starts over at page 53 three times in the second volume, and the Table of Contents has no page numbers. One wonders what exactly the AAA board was thinking when they accepted all this. Perhaps they all felt rushed, as some Task Force members said they were (e.g., Chernela 2009). Yet again, I'd ask, if you're taking your colleagues' reputations in your hands, shouldn't you take your time and get it right? 
In our interview, Jane Hill remarked to me, "we did not make an ethical accusation against [Chagnon]. But not everyone read it that way. I think [Chagnon] could have gotten a lot worse from us than he did" (Hill 2009). I am at a loss to explain what Hill is thinking here. Of course the Task Force made ethical accusations against Chagnon. And my conversations with Chagnon suggest, in fact, he could not have had it much worse from the AAA (Chagnon 2009).

Ironically, Chagnon might well have been better off had the institution where he is emeritus, University of California at Santa Barbara (UCSB), done a formal investigation of scientific misconduct rather than letting the AAA go off and run amok. Francesca Bray, who was the Chair of Anthropology at UCSB in 2000, recalled to me that the AAA's President Louise Lamphere called her to suggest that Chagnon's department take some kind of action to investigate or censure him. I asked Lamphere to confirm or deny this on the record, and she has not. But Bray remembers quite clearly Lamphere's call to her, at Bray's home. Bray wasn't sure how Lamphere even got her home number. Indeed, considering this extraordinary situation, Bray said to me, "I never thought I'd feel sorry for Nap." She added that Chagnon "certainly could be rough, but as a colleague at UCSB he was (if often provocative) reliable, straightforward, funny, and generous in his support to colleagues even when he disagreed with their theoretical bent" (Bray to Dreger, personal email communication, October 9, 2009).

If UCSB had mounted a formal inquiry, at least then Chagnon might have had a fair review as Neel did, posthumously, at Michigan, under the leadership of Provost Nancy Cantor and Ed Goldman in the General Counsel's office (Cantor 2000). If done fairly, university investigations, even if mounted in response to questionable politics, can result in clear and convincing findings. Michigan's outstanding response to Tierney matched in quality the University of Colorado's top-notch work on Ward Churchill. (I'll just note here, as a fascinating parallel to the accusations against $\mathrm{Neel}$, that one of the findings of the Colorado team was that Churchill had wrongly accused John Smith of starting an epidemic among "virgin soil" Native Americans in 1616. Churchill's claims against Smith stood in contradiction to clear evidence that the 1616 epidemic could not have been caused by Smith because Smith "left New England in 1614 and never returned" [Wesson et al. 2006:36].)

Gregor and Gross (2004) and others have argued that this whole Darkness mess was a battle between the scientifically-minded evolutionary anthropologists like Chagnon and anti-scientific postmodernists. Although I agree that Chagnon was often despised for his hardcore sociobiology, in fact, the critics of Chagnon and Neel have tried hard sometimes to appeal to documentary evidence, seemingly admitting that documentary evidence can constitute irrefutable, unambiguous proof of their claims. But they have done so selectively, as no scholar should. Indeed, this history raises questions about when sloppiness and selective source use reaches the threshold of misconduct, especially when what is at stake is another scholar's life's work. Truly, the fundamental problem here is not a school of thought that denies stable facts or documentation. Postmodernism may have contributed to this mess, but it is not the central problem. The central problem here is ideologically-driven pseudo-scholarship pretending it is real. 


\section{The Remaining Offenses}

According to Hill, Neel was cleared of all charges (Hill 2009). So what did Chagnon do wrong? According to the Task Force, after all these trials and tribulations, conclusively just two things:

First, ... his representations of Yanomami ways of life were damaging to them and ... he made insufficient effort to undo this damage, and second . . . his association in the early 1990s with FUNDAFACI, a Venezuelan foundation that sponsored his research, represented an unethical prioritizing of his own research concerns over the well-being of the Yanomami (AAA 2002a, vol. 1, p. 31).

Let's consider these, necessarily briefly, in reverse.

Chagnon was getting desperate, by the late 1980 s, to find ways to get back into Yanomamö-land to continue his work. Denied, via intense politicking, the ability to do this through the typical channels, he decided to team up with a group of wealthy Venezuelans associated as FUNDIFACI whose members included Charles BrewerCarias, a man with gold mining interests. Chagnon thus made alliances with people whose interests appeared unsavory.

I am not qualified to assess this incredibly complicated web of Venezuelan politics. I will simply say that the material about this, in the Task Force Report, does not approach standards required of a fair ethics investigation and smacks mostly of guilt by association. The Task Force's linking of Chagnon to a military coup reads like the game "six degrees of separation," although maybe there are only three degrees. Chagnon presented to me interesting point-by-point rebuttals to the most egregious alleged offenses of his work with FUNDIFACI. It would have been good if, like me, the AAA had formally asked Chagnon to explain. It would also have been good if, like me, the AAA had done enough digging to push Martins to admit that Tierney himself had written the permit-threatening, factually-challenged dossier that had led Chagnon to grow so desperate as to take actions like teaming up with FUNDIFACI.

As for Chagnon's supposed crime of having his representations of the Yanomamö used against them by the military, I will say this: When I read Chagnon's work on the Yanomamö, I see a deeply humanizing portrayal. But maybe that's because, like Chagnon, I don't see humans as angels. Yes, Chagnon sees in the Yanomamö evidence of treachery, greed, and violence. And he clearly sees that as evidence that they are like the rest of us.

In her continuing attempts to build a case against Chagnon as an abuser of the Yanomamö, Lêda Martins (2001) has used the following allegedly obnoxious quotation from Chagnon as it appeared in the magazine Veja: "Real Indians sweat, they smell bad, they take hallucinogenic drugs, they belch after they eat, they covet and at times steal their neighbor's wife, they fornicate, and they make war" (as translated in Borofsky 2005:309). What Martins does not reveal is that the remark from Chagnon continues thus: "They are normal human beings. This is reason enough for them to deserve care and attention" (in Borofsky 2005:309).

Should Chagnon have done more, as Martins claims, to run after people who misused his work in the service of their own nasty interests? First, I would say from 
my own experience as someone frequently quoted and sometimes misrepresented in the media, there is a limit to what any of us can do to control others' use of our work. There was, for example, a limit to what Chagnon could do when his remark in Veja was truncated by Martins and used against him as proof that he hurts the Yanomamö. (I have repeatedly asked Martins to explain the truncation, and she has not.)

Second, as Hames has noted, Chagnon did in fact try, on occasion, to halt misuse of his work, as when he found out his infanticide data might be used by a Venezuelan legislator to prosecute Yanomamö parents for murder (Hames 2005). Chagnon also tried to track down claims that Brazilian officials were using his work as the basis of harmful policies. He "asked a prominent Brazilian journalist, who follows both [Chagnon's] work and official Brazilian government policies as these relate to the Brazilian Yanomamö, to investigate this accusation." Euripedes Alcantara replied:

I can assure you that I could not find a trace of Brazilian officials['] use of your work as a justification of a certain policy towards the Yanomamö. I have asked people [in] high ranks of the military, Funai and the Congress. They have searched [at] my request almost all documents related to the Brazilian Indians policy. Nobody mentions your work as grounds for treating the Indians one way or another (quoted in Chagnon 2002).

Whether Alcantara is right or wrong, obviously it's false to conclude Chagnon did not worry about the use of his work by people who could harm the Yanomamö.

Should Chagnon have painted the Yanomamö to appear more gentle and lovable? I would answer that that could have been unethical, if it meant he put forth a representation that he saw as less than accurate. Though we should work hard not to inflict harm on our subjects, scholarship requires representing the world, including our subjects, as accurately as we can, even when that representation clashes with our sensibilities. To quote Adam Kuper:

If anthropology becomes . . . "the academic wing of the indigenous rights movement," if we report only what is convenient and refrain from analysing intellectual confusions, then our ethnographies will be worthless except as propaganda. Even as propaganda they will have a rapidly diminishing value, since the integrity of ethnographic studies will be increasingly questioned by the informed public (Kuper 2003:400).

In her criticism of Chagnon, the anthropologist Alcida Ramos has said this: "In Brazil as in other Latin American countries, professional anthropologists take on, as a matter of course, the social responsibility to both respect and defend the rights of our research subjects, particularly, indigenous peoples" (Ramos 2001). But I find such a construction - responsibility to defend our subjects - frightening. I admire, respect, and indeed identify with some of the work some anthropologists (like Bruce Albert) have done specifically to serve the dire needs of the Yanomamö. But advocacy is not scholarship; the former is specifically concerned with advancing human rights, the latter with the production of knowledge. To insist that scholars of a particular discipline adhere to and even advance preordained social politics looks to me frighteningly like the situation Galileo found himself in. 


\section{Saving Ourselves}

James Neel had believed the truth would save him. Before he died, he heard from Chagnon that something nasty and untrue about the 1968 epidemic was coming from Tierney. Chagnon had learned of it from a leak out of Norton (Chagnon 2009). So Neel left behind a folder marked "Yanomama-1968-Insurance," full of photocopies of primary source evidence of what had really happened on the ill-fated expedition (Lindee in Hagen et al. 2001:62). This turned out to be some of the material Lindee used, literally within days of the Turner-Sponsel memo, to show that Tierney's, Turner's, and Sponsel's most fundamental claims were false.

Meanwhile, unlike Neel, Chagnon was alive to experience what it is like to be drawn-and-quartered in the international press as a Nazi-like experimenter responsible for the deaths of hundreds, if not thousands, of Yanomamö. He tried to describe to me what it is like to suddenly find yourself accused of genocide, to watch your life's work be twisted into lies and used to burn you. I know from talking with other subjects of such counter-factual attacks just how brutalizing this sort of experience can be (Dreger 2008). Chagnon clearly had it the worst.

In 2009, through a lawyer, Chagnon finally forced the AAA to remove the Task Force report-including Kopenawa's claim that Chagnon paid his subjects to murder each other-from the AAA website. Astoundingly, in spite of the membership's vote in 2005 to rescind acceptance of the Task Force Report, the AAA had left the report up with no clearly attached note about its acceptance having been rescinded by the AAA membership. Chagnon also attempted, through his lawyer, to elicit a formal apology from the AAA. The leadership refused.

Although he has been understandably reluctant to speak on the record about this travesty of justice, James V. Neel, Sr.'s son, the physician James V. Neel, Jr., has given me permission to relay this statement: "It is impossible for me to adequately describe the distress caused to my mother and the rest of my family by the irresponsible actions of Tierney, Turner, Sponsel, and the AAA leadership. We are still waiting for a public apology" (personal email communication, December 27, 2010).

I did not know any of the major players in this history when I began researching it, but as is probably clear in this paper, what I found made me progressively outraged, and also sympathetic to Chagnon, Neel, and their families. The Chagnon and Neel families have been effusive in their thanks to me, and I believe at this point Chagnon considers me a friend, and I would call him my friend, although we hardly agree on everything. Jim Neel, Jr., and I have never met, but he called me his "hero" after my 2009 AAA presentation of this work (personal correspondence, December 15, 2009). By contrast, Terence Turner called me "demonic" in his interview with Inside Higher Education (Kolowich 2009), though he has yet to name anything I got wrong.

In other words, the past two years of this project has resulted in the development of various relationships - some complex - with some of those implicated. I think this was inevitable, and I hope, in reading this, scholars will keep in mind the facts as I have found them, and my documentation for those facts. Finally, I understand that those who were involved in this controversy may have had good intentions. Many sought justice. But justice that is meted out according to politics and not according to facts is the justice of the Middle Ages. If justice is not based on the facts, if 
principles of justice are not applied universally, there is no real justice. Forms of "scholarship" that deny evidence, that deny truth, that deny the importance of factseven if performed in the name of good - are dangerous not only to science and to ethics, but to democracy. And so they are dangerous ultimately to humankind.

Acknowledgments This work has been funded through a John Simon Guggenheim Memorial Foundation Fellowship and through generous research support of the Feinberg School of Medicine at Northwestern University. Substantial research assistance has been provided by Valerie Thonger. An earlier version of this work was presented at the American Anthropological Association meeting in Philadelphia in December 2009. The author thanks deeply the many individuals, too numerous to name, who provided interviews, source materials, and feedback on earlier versions of this work. She is especially indebted to Douglas W. Hume for his online archive of source material, and to Human Nature's editors and reviewers.

Open Access This article is distributed under the terms of the Creative Commons Attribution Noncommercial License which permits any noncommercial use, distribution, and reproduction in any medium, provided the original author(s) and source are credited.

\section{References}

Alberts, B. (2000). A statement from Bruce Alberts, President of the National Academy of Sciences: setting the record straight regarding Darkness in El Dorado. Washington, DC: National Academy of Sciences. (November 9.) Available at http://www.nku.edu/ humed1/darkness_in_el_dorado/documents/ 0538.htm.

American Anthropological Association. (2002a). El Dorado Task Force papers, submitted to the Executive Board as a final report May 18, 2002. 2 vols. Washington, D.C.: American Anthropological Association. Accessible through http://www.nku.edu/ humed1/darkness_in_el_dorado/documents/0535.htm.

American Anthropological Association. (2002b). Media advisory: El Dorado Task Force releases its final report, accepted by AAA Board with comments. (July 2). Available at http://www.nku.edu/ humed1/ darkness_in_el_dorado/documents/0516.htm.

American Anthropological Association. (2003). Referendum on Darkness in El Dorado \& danger to immunization campaign. Retrieved from http://www.nku.edu/ humed1/darkness_in_el_dorado/docu ments/0438.htm.

American Anthropological Association. (2005). Referendum to rescind The El Dorado Task Force Report. Retrieved from http://www.nku.edu/ humed1/darkness_in_el_dorado/documents/0440.htm.

American Society of Human Genetics. (2002). Response to allegations against James V. Neel in Darkness in El Dorado, by Patrick Tierney. American Journal of Human Genetics, 70(1), 1-10.

Baur, M. P., the IGES-ELSI Committee, et al. (2001). International Genetic Epidemiology Society: commentary on Darkness in El Dorado by Patrick Tierney. Genetic Epidemiology, 21, 81-104.

Borofsky, R. (2005). Yanomami: The fierce controversy and what we can learn from it. Berkeley: University of California Press.

Brown, P. (2000). Scientist 'killed Amazon Indians to test race theory.' The Guardian (September 23). Retrieved from http://www.guardian.co.uk/world/2000/sep/23/paulbrown.

Cantor, N. (2000). Statement from University of Michigan Provost Nancy Cantor on the book, "Darkness in El Dorado," by Patrick Tierney. Retrieved from http://ns.umich.edu/Releases/2000/Nov00/ r111300a.html.

Carneiro de Cunha, M. M. (1989). Letter to the Editor. Anthropology Newsletter, 30 (January), 3.

Chagnon, N. (1989). Letter to the Editor. Anthropology Newsletter, 30 (January), 3 \& 24.

Chagnon, N. (2002). Chagnon responds to Survival International's derogatory claims. (May 31) Retrieved from http://www.nku.edu/ humed1/darkness_in_el_dorado/documents/0204.htm.

Chagnon, N. (2009). Interview with Alice Dreger, Traverse City, Michigan, January 4, 2009. Approved version returned January 22, 2009.

Chernela, J. (2009). Telephone interview with Alice Dreger, August 10, 2009. Approved notes returned August 15, 2009.

Cohen, P. (2000). When two tribes go to war. New Scientist (November 11), 18. Retrieved from http:// www.nku.edu/ humed1/darkness_in_el_dorado/documents/0209.htm. 
Cox, R. S. (2001). Salting slugs in the intellectual garden: James V. Neel and scientific controversy in the information age. Mendel Newsletter (February) [electronic]. Retrieved from http://www.amphilsoc. org/mendel/2001.htm\#slugs.

Dreger, A. D. (2008). The controversy surrounding The Man Who Would Be Queen: a case history of the politics of science, identity, and sex in the Internet age. Archives of Sexual Behavior, 37(3), 366-421.

Ferguson, R. B. (1995). Yanomami warfare: A political history. Santa Fe: School of American Research Press.

Ferguson, R. B. (2009). Telephone interview with Alice Dreger, July 28, 2009. Corrections received October 1, 2009 and October 20, 2009.

Fox, R. (1994). Evil wrought in the name of good. Anthropology Newsletter, 35 (March), 2.

Frechione, J. (2001). Interview of Brandon S. Centerwall by John Frechione, October 27, 2001. Retrieved at http://www.nku.edu/ humed1/darkness_in_el_dorado/documents/0102.htm.

Frechione, J. (2009). Interview with Alice Dreger, Pittsburgh, July 8, 2009. Approved notes returned July $30,2009$.

Gregor, T. A., \& Gross, D. R. (2004). Guilt by association: the culture of accusation and the American Anthropological Association's investigation of Darkness in El Dorado. American Anthropologist, 106 (4), 687-698.

Hagen, E. H., Price, M. E., \& Tooby, J. (2001). Preliminary report, Department of Anthropology, University of California at Santa Barbara. Retrieved from http://www.anth.ucsb.edu/ucsbpreliminary report.pdf.

Hames, R. (2002). Letter of resignation from El Dorado Task Force. Retrieved from http://www.nku.edu/ rhumed1/darkness_in_el_dorado/documents/0514.htm.

Hames, R. (2005). The political uses of ethnographic description. In R. Borofsky (Ed.), Yanomami: The fierce controversy and what we can learn from it (pp. 119-135). Los Angeles: University of California Press.

Hames, R. (2009). Telephone interview with Alice Dreger, June 23, 2009. Approved version returned July 6, 2009.

Headland, T. N. (2001). When did the measles epidemic begin among the Yanomami? Anthropology News, 42(1), 15-19. Retrieved from http://www.sil.org/ headlandt/measles1.htm.

Hill, J. (2009). Telephone interview with Alice Dreger, July 15, 2009. Approved version received July 16, 2009.

Howell, J. (2001). Contextualizing the research. Journal of the International Institute [of the University of Michigan], (Fall), p. 26.

Johnston, B. R. (n.d.) Elements of the professional life of James V. Neel as reflected in the declassified literature on human radiation experimentation. Retrieved from http://www.nku.edu/ humed1/ darkness_in_el_dorado/documents/0109.htm.

Kolowich, S. (2009). Old wounds in anthropology. Inside Higher Ed (December 31). Retrieved from http://www.insidehighered.com/news/2009/12/03/eldorado.

Kuper, A. (2003). The return of the native: reply. Current Anthropology, 44(3), 400-402.

Lautman, V. (2000). Interview of Patrick Tierney on WBEZ Chicago (November 22). Transcribed by Valerie Thonger.

Lindee, S. (2008). Telephone interview with Alice Dreger, December 12, 2008. Revised version with approval received December 15, 2008.

Lindemann, H., et al. (2009). Open letter from the board of the American Society for Bioethics + Humanities. Response to the recent attacks on bioethicists (August 25). Retrieved from http://www. asbh.org/uploads/files/responsebrdltr.pdf.

Martins, L. L. (2001). On the influence of anthropological work and other considerations on ethics. Public Anthropology: Engaging Ideas (May 27). Retrieved from http://www.nku.edu/ humed1/darkness_ in el_dorado/documents/0480.htm.

Martins, L. L. (2009). Telephone interview with Alice Dreger, February 4, 2009. Approved notes returned March 25, 2009.

Miller, J. J. (2000). The fierce people: the wages of anthropological incorrectness. National Review, 52(22) (November 20), 45-47. Retrieved from http://www.nationalreview.com/20nov00/miller 112000.shtml.

Neel, J. V., Centerwall, W. R., Chagnon, N. A., \& Casey, H. L. (1970). Notes on the effects of measles and measles vaccine in a virgin-soil population of South American Indians. American Journal of Epidemiology, 91(4), 418-429.

Paul, D., \& Beatty, J. (2000). James Neel, Darkness in El Dorado, and eugenics: the missing context. The Society for Latin American Anthropology, 17 (November 1), (electronic newsletter). Retrieved from http://www.nku.edu/ humed1/darkness_in_el_dorado/documents/0380.htm. 
Peacock, J., Chernela, J., Green, L., Gruenbaum, E., Walker, P., Watkins, J., \& Whiteford, L. (2001). Report to Louise Lamphere, President of the American Anthropological Association, and the Executive Board of the American Anthropological Association. Recommendation for investigation of Darkness in El Dorado. [Known as "The Peacock Report."] (January 21). Available at http://www. nku.edu/ humed1/darkness_in_el_dorado/documents/0612.pdf.

Ramos, A. R. (2001). About ethics in ethnographic research. Journal of the International Institute [of the University of Michigan], (Fall) [no vol. or issue number], p. 7.

Saffirio, G. (2009). Interview with Alice Dreger, Cleveland, July 8, 2009. Approved notes received on August 12, 2009.

Salamone, F. A. (1997). Theoretical reflections on the Chagnon-Salesian controversy. In F. Salome \& W. R. Adams (Eds.), Explorations in anthropology and theology (pp. 91-112). Lanham: University Press of America.

Society for Visual Anthropology. (2000). Statement approved by the Board of Directors and unanimously passed by the membership of the Society for Visual Anthropology. Original source: http://etext.lib. virginia.edu/VAR/tim-resol.html. Retrieved from http://www.nku.edu/ humed1/darkness_in_el_dor ado/documents/0376.htm.

Sponsel, L. (1998). Yanomami: an arena of conflict and aggression in the Amazon. Aggressive Behavior, 24, 97-122.

Sponsel, L. (2009). Telephone interview with Alice Dreger, February 23, 2009. Approved notes returned March 2, 2009.

Tierney, P. (1994). Last tribes of El Dorado: The gold wars in the Amazon rain forest. New York: Viking. [Apparently never officially published; page citations are from a typeset, bound copy marked "advanced uncorrected proofs"].

Tierney, P. (2000). The fierce anthropologist. The New Yorker, (October 9), 50-61.

Tierney, P. (2001). Darkness in El Dorado: How scientists and journalists devastated the Amazon. New York: W. W. Norton.

Tooby, J. (2000). Jungle fever. Slate, (October 25). Retrieved from http://www.slate.com/id/91946/.

Turner, T[erence]. (1994). The Yanomami: Truth and consequences. Anthropology Newsletter, 35 (May), $48 \& 46$.

Turner, T[erence]. (2009). Telephone interview with Alice Dreger, February 4, 2009. Approved notes returned February 8, 2009.

Turner, T., \& Sponsel, L. (2000). Letter to Louise Lamphere and Don Brennis. "Re: Scandal about to be caused by publication of book by Patrick Tierney (Darkness in El Dorado. New York. Norton. Publication date: October 1, 2000).” Retrieved from http://www.nku.edu/ humed1/darkness_in_el_ dorado/documents/0055.htm.

Turner, T., \& Stevens, J. (2001). Annotated index of selected documents and correspondence from the collection of James V. Neel's papers in the Archive of the American Philosophical Society. Retrieved from http://www.umich.edu/ idpah/SEP/sep tn.html.

Turner, T[rudy] R. (2009). Telephone interview with Alice Dreger, August 24, 2009. Approved version returned September 16, 2009.

Turner, T. R., \& Nelson, J. D. (2004). Darkness in El Dorado: Claims, counter-claims, and the obligations of researchers. In T. R. Turner (Ed.), Biological anthropology and ethics: From repatriation to genetic identity (pp. 165-183). New York: State University of New York Press.

Wesson, M., et al. (2006). Report of the investigative committee of the Standing Committee on Research Misconduct at the University of Colorado at Boulder concerning allegations of academic misconduct against Professor Ward Churchill. Boulder: University of Colorado. Retrieved from www.colorado. edu/news/reports/churchill/download/WardChurchillReport.pdf.

Wolf, E. R. (1994). Demonization of anthropologists in the Amazon. Anthropology Newsletter, 35 (March), 2.

Alice Dreger is a Professor of Clinical Medical Humanities and Bioethics at Northwestern University's Feinberg School of Medicine. She holds a Ph.D. in History and Philosophy of Science from Indiana University. Her books include Hermaphrodites and the Medical Invention of Sex (Harvard University Press, 1998) and One of Us: Conjoined Twins and the Future of Normal (Harvard University Press, 2004). She is currently completing a Guggenheim-funded book on scientific controversies in the Internet age, a project from which this article's content is drawn. 